\title{
Tunisian phosphogypsum tailings: Assessment of leaching behavior for an integrated management approach
}

\author{
Raja Zmemla ${ }^{1}$, Ali Sdiri ${ }^{\dagger}$, Ikram Naifar ${ }^{1}$, Mounir Benjdidia ${ }^{3}$, Boubaker Elleuch ${ }^{1}$ \\ ${ }^{1}$ Laboratory of Environmental Engineering and Ecotechnology, National Engineering School, University of Sfax, P. Box 1173-3038 Sfax, Tunisia \\ ${ }^{2}$ Department of Georesources and Environment, National Engineering School, University of Sfax, P. Box 1173-3038 Sfax, Tunisia \\ ${ }^{3}$ Department of Civil Engineering, National Engineering School, University of Sfax, P. Box 1173-3038 Sfax, Tunisia
}

\begin{abstract}
This study has been carried out to evaluate the leaching behavior of Tunisian phosphogypsum (PG) tailings in Skhira city (southern Tunisia). Two PG samples, including old and freshly deposited samples, were characterized in terms of physical, geotechnical, mechanical, chemical and mineralogical properties. Special attention was paid to their leaching behavior when subjected to standard leaching tests. Our results indicated that both samples are mainly composed of more than $31.85 \% \mathrm{CaO}$ and $31.4 \% \mathrm{SO}$, indicating the predominance of gypsum. This was further confirmed by XRD patterns that revealed the presence of characteristic reflections of gypsum, brushite, quartz and Maladrite. Compressive strength after $90 \mathrm{~d}$ exceeded $769 \mathrm{kPa}$, but still lower than that of natural sand $(1,800 \mathrm{kPa})$. Leaching test was proposed as an appropriate method to determine the released contaminants from PG. The obtained results showed that Fluorine and Phosphorus are the most released elements from PG with 40 and 30\%, respectively. The released Se, Cd, and $\mathrm{Zn}$ were the only trace elements that exceeded the threshold limits. It seemed that leached element concentrations were independent aging or particle size of the PG. Based on the assessment of leaching behavior, an integrated management approach of the PG deposits was proposed.
\end{abstract}

Keywords: Characterization, Geotechnical properties, Heavy metals, Leaching, Mechanical Behavior, Phosphogypsum

\section{Introduction}

Phosphogypsum (PG) is an industrial solid by-product generated during the production of phosphate fertilizers via chemical processing known as «wet process» by which apatite (mainly as fluorapatite $\left.\mathrm{Ca}_{10}\left(\mathrm{PO}_{4}\right)_{6} \mathrm{~F}_{2}\right)$ reacted with sulfuric acid $\left(\mathrm{H}_{2} \mathrm{SO}_{4}\right)$ [1,2] to produce phosphoric acid $\left(\mathrm{H}_{3} \mathrm{PO}_{4}\right)$. Wet process generates a large amount of PG [3], exceeding 280 million tons per year worldwide [4]. Of which, only $14 \%$ is being revalorized, $28 \%$ is dumped into the receiving water bodies and $58 \%$ is being stockpiled [5]. PG is mainly composed of calcium sulfate dehydrate $\left(\mathrm{CaSO}_{4} 2 \mathrm{H}_{2} \mathrm{O}\right)$ with numerous impurities like heavy metals, rare earths elements and naturally occurring radioactive materials [6, 7]. Many studies have addressed trace elements contents in PG from different locations worldwide (South Africa, Tunisia, Syria, Florida, Spain, Idaho); they showed ranges of 6-103 mg/kg for $\mathrm{Cu}$; 6-315 mg/kg Zn; 0.8-40 mg/kg Cd; 2-43 mg/kg Ni; 6-135 mg/kg U and 3-7 mg/kg Pb [8]. For instance, Pérez-López et al. [9] extensively studied the impact of spanish
PG stacks on the ecosystem. They found that salt-marshes play key role in the natural attenuation of contamination. In a further trial to evaluate the pollutant flows from phophogypsum area [10] , the same author proposed to carry a preliminary restoration plan to overcome the tidal-induced leaching. Papageorgiou et al. [11] run a radiological study in the Shistos PG stack (Piraeus, Greece) using a combination of gamma ray spectroscopy and GIS based technique. They had posited that environmental risk by radioactivity in Shistos area would be minimized by simple thick soil cover and geomembrane. Kassir et al. [12] had attempted to valorize PG in soil amendment via the assessment of selected trace elements in Mediterranean red soil from Lebanon. They concluded that soil amendment by PG is feasible and viable due to low environmental impact of trace elements, that remained below the threshold limits required by relevant Lebanese regulations. Similarly, Tunisian chemical group (TCG), a series of factories for phosphoric acid production generated important tonnage of PG. Phosphate industry is, thus, responsible for the generation of more than 12 million
This is an Open Access article distributed under the terms of the Creative Commons Attribution Non-Commercial License (http://creativecommons.org/licenses/by-nc/3.0/) which permits unrestricted non-commercial use, distribution, and reproduction in any medium, provided the original work is properly cited.

Copyright (C) 2020 Korean Society of Environmental Engineers
Received February 7, 2019 Accepted May 16, 2019

${ }^{\dagger}$ Corresponding author

Email: ali.sdiri@enis.rnu.tn

Tel: +216-97-856-716 Fax: +216-74-275-595

ORCID: 0000-0003-3446-9651 
tons of PG that need to be correctly managed and stored [13]. This huge volume is expected to increase in the near future, especially with the exploitation of the new layers [13]. Management of these large quantities is one of the most challenging environmental problem in many countries [14]. To limit the potential impact of those by-products, several studies have been undertaken with an attempt to valorize PG in various industrial and agricultural applications, including building materials [15-19], agricultural fertiliser [20-22] and soil amendments [12, 23, 24]. The long-term management of PG is directly related to the problem of potentially toxic elements leaching. Therefore, monitoring the high volume of PG as embankment near the treatment unit needs a detailed study about its long-term behavior and/or evolution of heavy metals content. Unlike several wastes such as fly ash, sediments, till now there are no specific regulations for the management of PG. Classification and characterization of PGs based on current legislations are not well known due to the fact that most studies on PG have focused on the environmental impact of this waste on the surrounding landfilling area, but not on the possible species leaching. Published studies, in Tunisia, have focused mainly on the spatial characterization of pollution near PG storage areas, by mapping the concentration levels of chemical elements and specifying contaminated areas [23, 25, 26]. But, no clear results on the quantification of released pollutants (trace elements, heavy metals,...) contained in Tunisian PGs. The assessment of the real potential release of trace elements, through PG leaching tests, is a viable tool to investigate the leaching behavior. In this context, the present study has been carried out to fill the gap caused by the lack of information about the possible time-dependent evolution of PG embankment. Technological characterization (i.e., physical, geotechnical and mechanical properties) and evaluation of leaching behavior of the studied PG samples may serve as handy tools to draw a complete synopsis of this by-product for an integrated management of the PG deposits. The effect of long term storage ( $>20 \mathrm{y}$ in outdoor stockpile) on the physical, mechanical and chemical properties of Tunisian PG was also advised. The innovative aspect discussed in the current study concerned early insights on the leaching behavior of trace elements from PG in the Skhira embankment. The main objective of the current work is, therefore, to (1) characterize the phosphate processing by-product (i.e., PG); (2) quantify the leached amount of pollutants from Tunisian PG stack and (3) propose an integrated management approach based on an UpToDate standards.

\section{Materials and Methods}

\subsection{Samples Preparation}

Two PG samples (fresh and aged) were collected from the TCG phosphoric acid production unit of Skhira lying $80 \mathrm{~km}$ to the south of Sfax city, southern Tunisia ( $\left.34^{\circ} 20^{\prime} 50^{\prime \prime} \mathrm{N} ; 10^{\circ} 08^{\prime} 50^{\prime \prime} \mathrm{E}\right)$. About 200 $\mathrm{kg}$ of PG were collected from each sampling point (Fig. S1). At the laboratory, PG samples were homogenized and stored in plastic bags; subsamples were taken from the raw PG for subsequent physico-chemical analysis. Aged PG sample was then fractionated into two different particle-sized subsamples (less than $45 \mu \mathrm{m}$ and more than $125 \mu \mathrm{m}$ sized-fractions) to assess the effect of particle size on PG leachability. Hereafter, we used PGF and PGA to refer to the fresh and aged PGs samples, respectively. We attributed acronyms of PGAf and PGAc for PGA subsamples of fine (i.e., less than $45 \mu \mathrm{m}$ ) and coarse fraction (more than $125 \mu \mathrm{m}$ ). Physical, geotechnical and mechanical performances of PG samples were compared to a natural sand (NS) commonly used in road material.

\subsection{Physico-mechanical characterization}

Physical characterization of both samples included the determination water content, bulk and real density, grain size distribution using the dry sieving method. Further information about particle size distribution was obtained using laser granulometry in wet suspensions [27]. Additionally, microstructure of PG was assessed by scanning electron microscope, (SU 8010 Hitachi) at $30 \mathrm{kV}$.

Geotechnical analyses through Proctor modified test and California Bearing Ratio (CBR) were carried out as described elsewhere [28-31]. The modified proctor compaction test in combination with CBR was used to determine the optimal moisture content (OMC) with the corresponding maximum dry density (MDD). Thereafter, cylindrical specimens (with diameter of $50 \mathrm{~mm}$ and height of $100 \mathrm{~mm}$ ) were compacted using geotechnical results obtained from the modified compaction to determine mechanical behavior of PG studied samples. All specimens were prepared with the modified compaction method at the optimum moisture content (OMC) and maximum density determined by the standard compaction test. The specimens were remolded and stored for testing after 28 and 90 curing days. To achieve this goal, an experimental setup was developed according to the diagram shown in Figure S2. Specimens were used for compressive strength (RC) and tensile strength (RT) determination according to Morel et al. [32] by using a compression devise type ELLOYD LR $50 \mathrm{~K}$, at a loading speed of $1.25 \mathrm{~mm} / \mathrm{min}$. Coefficient of permeability was measured according to Ajam et al. [15]. Briefly, permeability test measures the time elapsed by a given fluid to pass through the sample column under a constant pressure [33].

\subsection{Chemical and Mineralogical Characterization}

To ascertain the composition of PGA and PGF samples, about 200 mg of each PG sample were ground to less than $45 \mu \mathrm{m}$-sized fraction. Then, $10 \mathrm{~mL}$ of $5 \mathrm{M} \mathrm{HNO}_{3}$ was added to the Teflon beaker containing the desired PG powder under heating temperature of $120^{\circ} \mathrm{C}$ below a fume hood for $2 \mathrm{~h}$. After the total dissolution of PG powder, the obtained solution was allowed to dry for $2 \mathrm{~h}$. Finally, UPW was added to wash out the residual nitric acid; the whole was transferred to $100 \mathrm{~mL}$ volumetric flask and adjusted [34]. Chemical composition of PG was determined by ICP-AES (Jobin-Yvon Horiba Ultima-C2000). To measure the concentration of both major and trace elements, an acid digestion methodology was adopted as described above; $\mathrm{H}_{2} \mathrm{O}_{2}$ was dropwise added to remove any organics.

Alkaline dissolution of the PG powder was also undertaken by the addition of $\mathrm{LiBO}_{2}$ for comparative purposes.

Fluoride was analyzed by means of an $\mathrm{F}^{-}$selective electrode (Metrohm 781pH/ion meter). Measurements of fluoride anions were made on sample solution prediluted with an equal amount of total ionic strength adjustment buffer to reduce the variation of the ionic strength, this buffer contains a product which forms complexes 
with other ions that could interfere in the determination of Fluoride and it is the decomplexing agent that releases all complexed $\mathrm{F}$ into free fluoride ions.

Mineralogical analysis of the PG samples (i.e., PGA and PGF) was performed by using an $\mathrm{X}$ ray bruker diffractometer (X'Pert Pro MPD Panalytical) with Co K $\alpha$ radiation (1.79 $\AA$ ), running at $35 \mathrm{kV}$ and $40 \mathrm{~mA}$ with a total counting time of $10 \mathrm{~h}$. The obtained XRD patterns were computer processed using the X'Pert High score plus software and compared to the international center of diffraction Data PDF-2 database to identify the main mineral phases.

\subsection{Batch Leaching Tests}

Batch leaching test was used as a handy tool to assess the mobility of major and trace elements according to the description of Papaslioti et al. [35]. Briefly, batch leaching test was performed by using ultra-pure water (UPW) as leachate. Samples were leached at a liquid solid (L/S) ratio of $10 \mathrm{~L} / \mathrm{kg}$ in UPW at $25^{\circ} \mathrm{C}$ for $24 \mathrm{~h}$ under continuous shaking. Then, about $10 \mathrm{~mL}$ from the supernatants were withdrawn through $0.45 \mu \mathrm{m}$ syringe-driven millipore filters (Millex-LH, PTFE, Millipore Corp., France), acidified with $\mathrm{HNO}_{3}$ acid ( $5 \mathrm{~mol} / \mathrm{L}$ ) and stored for subsequent chemical analysis by ICP-AES as shown in Bisone et al. [36]. Measurements concerned both major and trace elements (e.g., $\mathrm{Al}_{2} \mathrm{O}_{3}, \mathrm{CaO}, \mathrm{Fe}_{2} \mathrm{O}_{3}, \mathrm{~K}_{2} \mathrm{O}, \mathrm{MgO}$, $\mathrm{Na}_{2} \mathrm{O}, \mathrm{P}_{2} \mathrm{O}_{5}, \mathrm{SiO}_{2}, \mathrm{TiO}_{2}, \mathrm{Sr}, \mathrm{Cs}, \mathrm{Zn}, \mathrm{Cu}, \mathrm{Y}, \mathrm{Ni}, \mathrm{Ba}$, As and Cd). Other parameters including $\mathrm{pH}$ and electric conductivity (EC) of the eluates were also monitored.

\section{Results and Discussion}

\subsection{Effect of Long-Term Storage on the PG Physico-Chemical Properties}

\subsubsection{Physical and geotechnical properties}

Physical, geotechnical and mechanical properties of the studied Tunisian PG are summarized in Table 1. It was found that both samples contained somewhat high moisture contents exceeding 4\% for PGF and 7\% for PGA. These results showed that fresh PG (i.e., PGF) contained the highest water content (7\%), when compared to NS (1.01\%; [37]) and natural gypsum (1-2\%; [15]). Usually, PG from cake has a high free moisture contents ranging between $25-30 \%$ [33, 38]. The free water content is largely variable depending on the production process, especially the filtration of PG; it depends also on how long the PG has been allowed to drain after stacking and on local weather conditions. Measured water contents of fresh and aged PG samples (i.e., PGA, PGF), varied between 4-7\%, respectively, showing lower values than those reported by Sfar Felfoul et al. [33] and Rouis [38] who studied PGs of Sfax area whose water contents varied between 19 to $30 \%$. Likewise, El Cadi et al. [39] studied the phosphogysum from marrackech area- Morocco; they found 12 to $27 \%$ water contents. Those values are much higher than those reported in this study, probably because of the separation procedure adopted by the Skhira unit for phosphoric acid production (dry process) as well as climatic conditions during storage on tailings (high temperature in arid climate). It is therefore possible to conclude that the studied samples are continuously subjected to natural drying.
Both PG samples showed apparent densities of 0.83 and $0.81 \mathrm{~g} / \mathrm{cm}^{3}$; the absolute density ranged between 2.33 and $2.34 \mathrm{~g} / \mathrm{cm}^{3}$, indicating a typical range for natural gypsum $\left(2.3 \mathrm{~g} / \mathrm{cm}^{3}\right)$. Similar results were shown in previous relevant studies [15, 38, 40]. Generally, PGs particle density ranges between 2.27 and $2.4 \mathrm{~g} / \mathrm{cm}^{3}$ (absolute density) and its bulk density 0.8 and $1.5\left(\mathrm{~g} / \mathrm{cm}^{3}\right)$ [15].

Based on these results, it can be concluded that PG is a light material compared to NS $\left(2.65 \mathrm{~g} / \mathrm{cm}^{3}\right)$. The absolute and apparent densities of the studied PGs samples are comparable to those presented by Schaeffner [41] who studied PGs of sedimentary origin. However, they are lower than those of PG of magmatic origin [41]. Furthermore, the obtained results are close to those of natural gypsum [42, 43] but lower than NS, showing a very light and less dense material.

From granulometric analysis, it appears that PG samples from the Skhira embankments are mainly composed of very fine materials (Fig. 1). Indeed, 65 to $75 \%$ of PG fraction is smaller than $80 \mu \mathrm{m}$. The fresh sample (PGF) showed higher content of fine fraction than old PG one (i.e., PGA) due to segregation and weathering in stockpile. Further investigation by Laser granulometry showed that D50s of the studied PGF sample varied between 40 and 50 $\mu \mathrm{m}$, favoring the physical interactions between particles. The obtained results are consistent with those presented for the PG Tunisian [15] and for other PG from Canada [44], Morocco [45-47] and Turkey [48]. Grain size distribution allowed the classification of PG samples as sandy loam; the percentage of the less than 80 $\mu \mathrm{m}$ sieve varied between 60 and $75 \%$ (Table 1).

OMC and MDD of the studied PG samples were listed in Table 1. Those geotechnical properties showed an OMC of 18.5\% for PGF and $14.9 \%$ for PGA due to the influencing grain size distribution [38]. The modified compaction test results indicated that both fresh and old PG have the high OMC values (i.e., 14.9-18.5\%), but lower value of MDD than NS. These results are consistent with the finer granulometry of the studied phsophogypsum stock, its higher initial

Table 1. Physical, Geotechnical and Mechanical Properties of the Used Samples

\begin{tabular}{|c|c|c|c|c|}
\hline \multicolumn{2}{|l|}{ 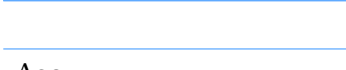 } & PGF & PGA & NS \\
\hline \multicolumn{2}{|l|}{ Age } & $2 \mathrm{~m}$ & $20 \mathrm{y}$ & - \\
\hline \multicolumn{2}{|c|}{ Water content (\%) } & 7 & 4 & 1.5 \\
\hline \multicolumn{2}{|c|}{ Bulk density $\left(\mathrm{g} / \mathrm{cm}^{3}\right)$} & 0.83 & 0.81 & 1.54 \\
\hline \multicolumn{2}{|c|}{ Real density $\left(\mathrm{g} / \mathrm{cm}^{3}\right)$} & 2.34 & 2.33 & 2.65 \\
\hline \multirow{2}{*}{$\begin{array}{l}\text { Particle } \\
\text { size }\end{array}$} & $\%<80 \mu \mathrm{m}$ & 75 & 65 & 2 \\
\hline & $\mathrm{D}_{50}(\mu \mathrm{m})$ & 40 & $50-400$ & - \\
\hline \multirow{2}{*}{ MP } & $\mathrm{MDD}\left(\mathrm{g} / \mathrm{cm}^{3}\right)$ & 1.33 & 1.45 & 1.81 \\
\hline & OMC (\%) & 18.5 & 14.86 & 12.4 \\
\hline \multirow{2}{*}{ CBR } & CBR soaked & 17 & 48 & 65 \\
\hline & CBR usoaked & 5 & 15 & 61 \\
\hline \multicolumn{2}{|l|}{$\mathrm{K}\left(\mathrm{cm} / \mathrm{s}^{1}\right)$} & $3.710^{-4}$ & $2.310^{-5}$ & $4.710^{-6}$ \\
\hline \multirow{2}{*}{$\mathrm{RC}(\mathrm{kPa})$} & $28 \mathrm{~d}$ & 494 & 776 & 1,800 \\
\hline & $90 \mathrm{~d}$ & 769 & 1,114 & 1,800 \\
\hline \multirow{2}{*}{$\mathrm{RT}(\mathrm{kPa})$} & $28 \mathrm{~d}$ & 55 & 85 & 355 \\
\hline & $90 \mathrm{~d}$ & 112 & 210 & 360 \\
\hline
\end{tabular}




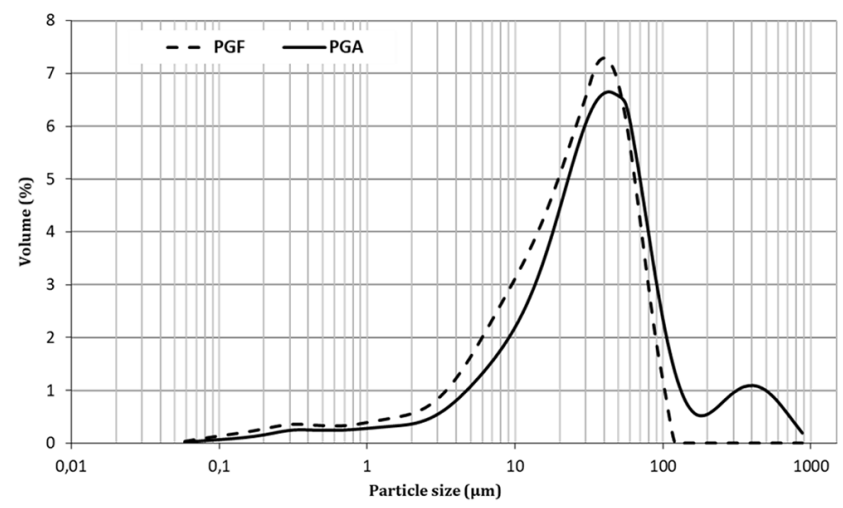

Fig. 1. Particle- size distribution of PGs.
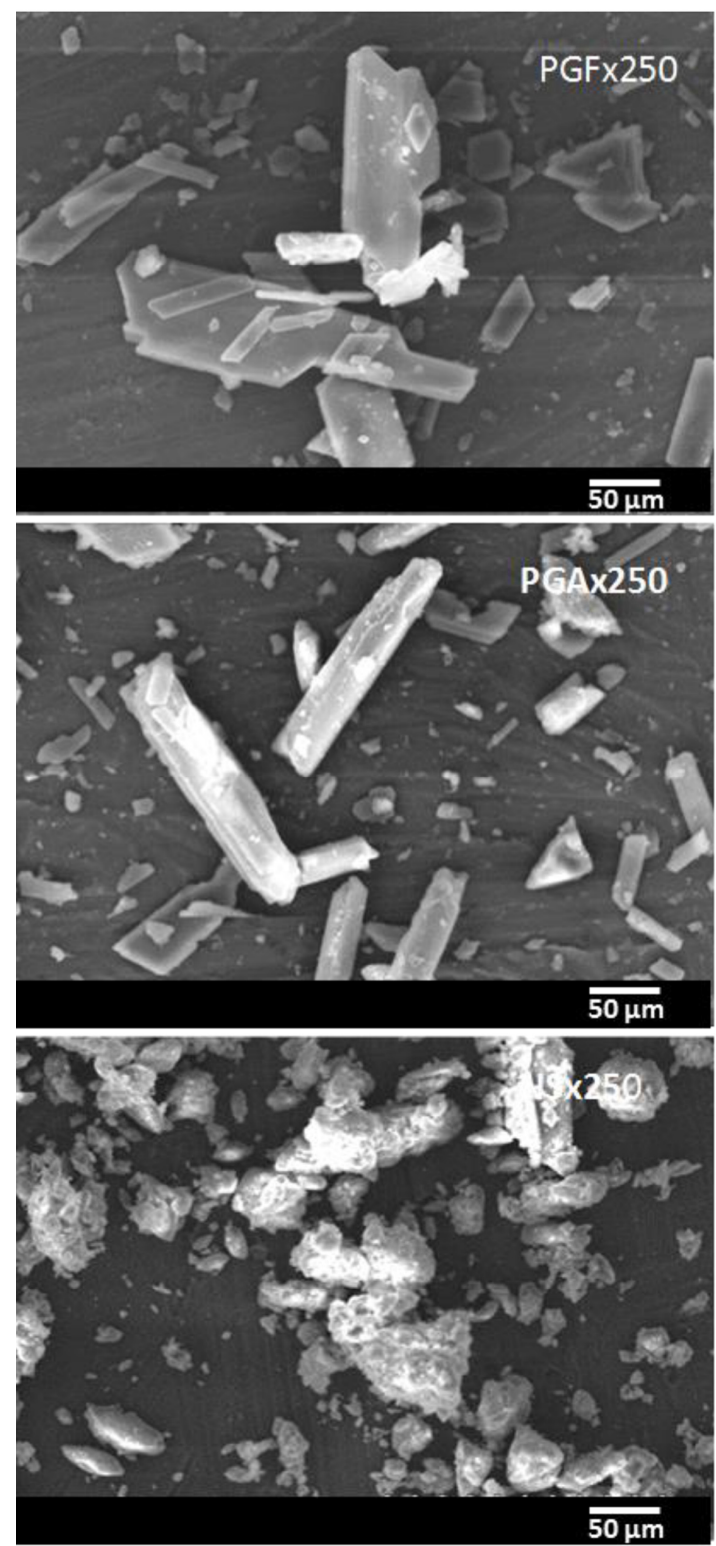

Fig. 2. SEM images of PGF, PGA and NS samples. water content combined with lower particle density. Low MDD values can be attributed to the low specific gravity with regards to NS. CBR tests were 17 and 48 for soaked PGF and PGA samples, respectively. Those values sharply decreased to 5 and 15 for the unsoaked respective samples, indicating very sensitive material to water.

In summary, one can easily recognize that PG samples from Skhira embarkment has optimal dry densities of $1.3-1.4 \mathrm{~g} / \mathrm{cm}^{3}$, and optimal water contents of $15-18 \%$. Those parameters are comparable to the results presented by Sfar Felfoul et al. [33] and Rouis [38]. Furthermore, the CBR index showed a clear drop after immersion in water. Similarly, the mechanical performance in terms of compressive and tensile strengths showed that the PGA sample has higher mechanical performances than the fresh PGF sample, but they remained less important than those of NS. As shown
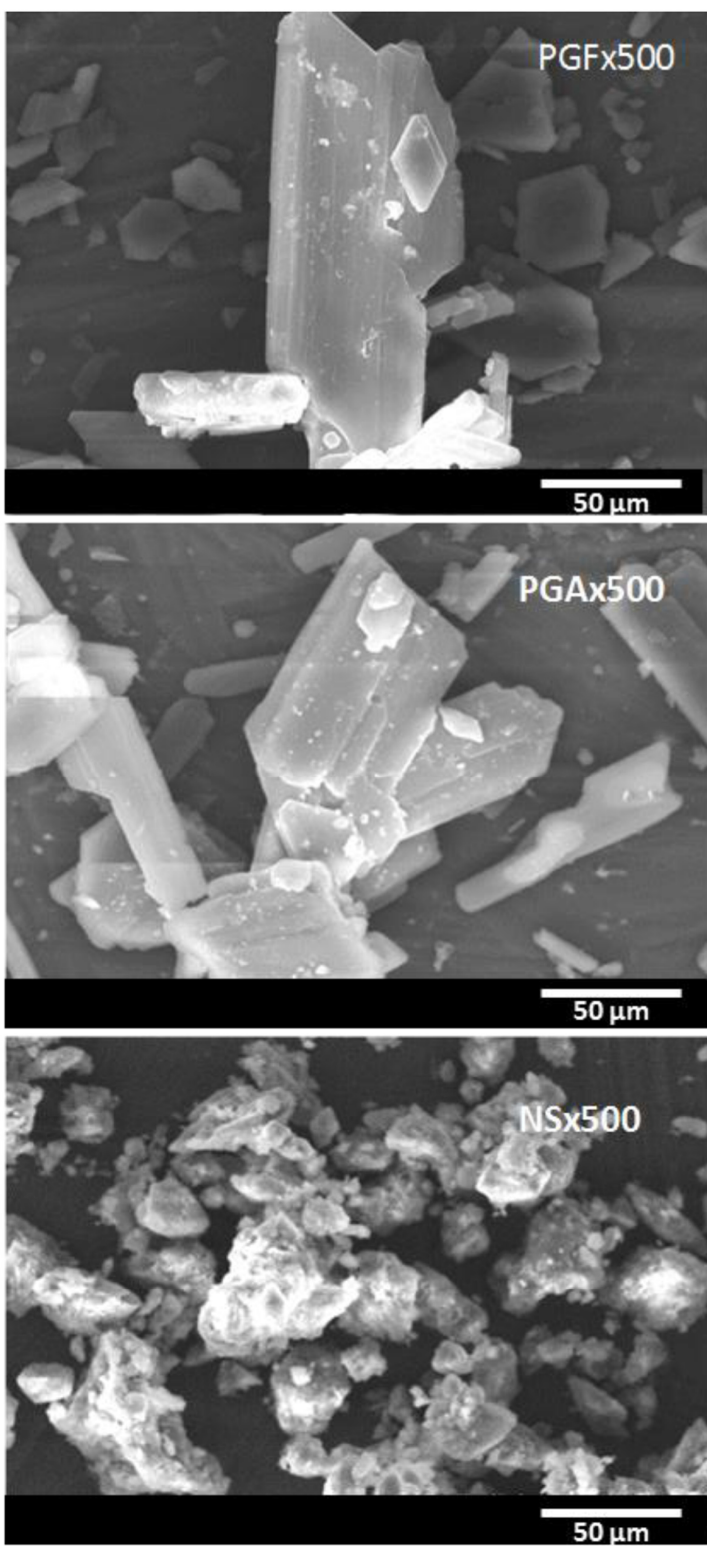
in Table 1, the compressive and the tensile strength of both PG samples for 28 and 90 curing days are lower than those of NS. The old PGA sample exhibited higher compressive resistance and strength than those of PGF. However, both have less performance than NS. Data showed increased values with curing period. Strength of early age $(28 \mathrm{~d})$ reached $60 \%$ of the final RC. The development of resistance is more important at younger age under the effect of drying. Earlier studies have reported that moisture content, compaction energy, free acid content, and organic matter content are important determinants of PG resistance [31, 49, 50].

Hydraulic conductivity measures have been conducted on both PG samples (PGF and PGA) as well on NS for comparative purposes. The obtained values, given in Table 1 , showed $3.710^{-4} \mathrm{~cm} / \mathrm{s}$ for PGF and $2.310^{-5} \mathrm{~cm} / \mathrm{s}$ for PGA. This may indicate that freshly produced PG sample is the more permeable than PGA. Thus, aging has clearly improved the hydraulic characteristic of the PG, but lower than those of the NS $\left(4.710^{-6} \mathrm{~cm} / \mathrm{s}\right)$. Sfar Felfoul et al. [33] reported a hydraulic conductivity range of $10^{-3}-10^{-5} \mathrm{~cm} / \mathrm{s}$, which is in agreement with the present PGA and PGF PGs.

Microstructural analysis, carried out by electron microscopy, revealed the abundance of particles with a diameter between 10 and $100 \mu \mathrm{m}$ (Fig. 2). This is consistent with the particle size analyses carried out by dry sieving. Furthermore, the observations showed the tabular crystalline morphology of PGs, as was the case for most PGs from apatite of sedimentary origin [51]. The comparison between the fresh and the aged PG showed that PG is prone to physical modifications on pile, exactly as explained by Sfar Felfoul et al. [33,40]. Compared to NS, PG particles are regular in form and small with abundant needle-like crystals, especially for PGA sample.

\subsubsection{Effect of long-term storage on chemical composition}

Table 2 shows the chemical composition of both PG samples. It provides a comparison of those components in PG (max-min) from relevant literature [39]. PG samples are mainly composed of $\mathrm{CaO}$ and $\mathrm{SO}_{3}$. $\mathrm{CaO}$ contents were $31.85 \%$ for PGF and $35.03 \%$ for PGA. Those of $\mathrm{SO}_{3}$ reached $31.4 \%$ for PGF and $38.66 \%$ for PGA. Both elements represent about $70 \%$ of the total weight. In the PGAf and PGAc, $\mathrm{CaO}$ contents reached $34.04 \%$ for the aged PGAc subsample. In contrast, low amounts of $\mathrm{F}, \mathrm{SiO}_{2}, \mathrm{P}_{2} \mathrm{O}_{5}$ and $\mathrm{Al}_{2} \mathrm{O}_{3}$, $\mathrm{Fe}_{2} \mathrm{O}_{3}, \mathrm{~K}_{2} \mathrm{O}, \mathrm{MgO}$ and $\mathrm{TiO}_{2}$ were observed.

Trace elements contents showed somewhat high concentration of heavy metals with the most abundant trace metal are As, Ba, $\mathrm{Cd}, \mathrm{Cu}, \mathrm{Ni}, \mathrm{Sr}, \mathrm{Y}$ and $\mathrm{Zn}$; The lowest concentration values were observed for $\mathrm{Cr}, \mathrm{Pb}, \mathrm{Zr}, \mathrm{V}$, Se and Hg (Table 2). These concentrations are in agreement with those for PG from sedimentary phosphate rock reported by El Cadi et al. [39], except concentrations of $\mathrm{Sr}$ and $\mathrm{Zn}$, perhaps due to an enrichment in $\mathrm{Zn}$ and $\mathrm{Sr}$ from the original phosphate rocks.

Further investigation indicated that old PGA sample was slightly enriched of As, Ba, Cd, Ni, Pb, Y, Hg, Y, but not for $\mathrm{Zn}$ that presented seven times higher concentrations than PGF. As for other elements (i.e., Cr, Cs, Cu, Se and Sr), PGA presented lower concentrations with low enrichment factor $(<1)$ for only As, Cs and Sr (Table 3).

According to the values obtained, no notable tendency of trace metal concentrations was detected according to the age. Previous studies have drawn the same conclusions for Brazilian, Syrian, Jordan and Spain PG which dumped in stockpiles [6, 10, 33, 52-54]. Due to the heterogeneity in the distribution of major and heavy metal, comparison of fresh and old PG did not give satisfactory information about the chemical behavior of PG. That is why, laboratory leaching tests were used to measure the released element concentration from waste for better prediction of long term impact [54].

\subsubsection{Mineralogical analysis by XRD}

XRD patterns of the studied PGA and PGF samples revealed the presence of characteristic reflections of gypsum $\left(\mathrm{CaSO}_{4} \mathrm{H}_{2} \mathrm{O}\right)$ as the dominant mineral phase, subordinated by minor Brushite $\left(\mathrm{CaPO}_{3}(\mathrm{OH}) \mathrm{H}_{2} \mathrm{O}\right)$, Quartz $\left(\mathrm{SiO}_{2}\right)$ and Maladrite $\left(\mathrm{NaSiF}_{6}\right)$. Basal reflection near 7.56, 4.26, 3.79, 3.16, 3.05, 2.86, 2.78, 2.67 and $2.59 \AA$ suggested the presence of gypsum [43]. Brushite can be observed in the $3.047 \AA$ and $3.78 \AA$ reflections [55]. As for quartz, the only reflection appeared near $4.26 \AA$ [56]. Maladrite $\left(\mathrm{NaSiF}_{6}\right)$ may appear near $4.435 \AA$ (Fig. 3a). The superposition of the different XRD diffractograms of the PGs indicated a mineralogical stability

Tabl 2. Major Elements Contents of the Studied PG Samples (\% by weight)

\begin{tabular}{lcccccccccccccc}
\hline Sample & $\mathbf{H}$ & $\mathbf{O M}$ & $\mathbf{L O I}$ & $\mathrm{Al}_{2} \mathbf{O}_{3}$ & $\mathbf{C a O}$ & $\mathbf{F}$ & $\mathbf{F e}_{2} \mathbf{O}_{3}$ & $\mathbf{K}_{2} \mathbf{O}$ & $\mathbf{M g O}$ & $\mathbf{N a}_{2} \mathbf{O}$ & $\mathbf{P}_{2} \mathbf{O}_{5}$ & $\mathbf{S i O}_{2}$ & $\mathbf{T i O}_{2}$ & $\mathbf{S O}_{3}$ \\
\hline PGF & 21.21 & 8.89 & 1.89 & 0.69 & 31.85 & 0.92 & 0.03 & 0.02 & 0.01 & 0.483 & 0.81 & 1.86 & 0.04 & 31.4 \\
PGA & 1.06 & 16.62 & 1.5 & 0.65 & 35.03 & 0.64 & 0.07 & 0.04 & 0.01 & 0.856 & 1.24 & 4.45 & 0.03 & 38.66 \\
PGAf & 2.25 & 12.85 & 2.93 & 0.72 & 33.69 & 1.24 & 0.08 & 0.06 & 0.01 & 0.36 & 1.18 & 1.87 & 0.04 & 42.73 \\
PGAc & 1.12 & 16.3 & 2.17 & 0.91 & 34.04 & 0.66 & 0.08 & 0.02 & 0.01 & 0.51 & 0.82 & 3.45 & 0.04 & 39.89 \\
\hline
\end{tabular}

OM: organic matter; LOI: Loss on ignition, H: humidity

Table 3. Trace Elements Contents $(\mathrm{mg} / \mathrm{kg})$ of the PG Samples

\begin{tabular}{lcccccccccccccc}
\hline Sample & As & Ba & Cd & $\mathbf{C r}$ & $\mathbf{C u}$ & $\mathbf{H g}$ & $\mathbf{N i}$ & $\mathbf{P b}$ & $\mathbf{S e}$ & $\mathbf{S r}$ & $\mathbf{V}$ & $\mathbf{Y}$ & $\mathbf{Z n}$ & $\mathbf{Z r}$ \\
\hline PGF & 15 & 30.22 & 24.73 & 6.12 & 70.82 & 1.99 & 49.61 & 8.06 & 4.42 & 1465 & 6.29 & 94.46 & 93.2 & 9.17 \\
PGA & 21 & 29.33 & 12.23 & 6.12 & 69.08 & 0.29 & 34.82 & 6.67 & 0.95 & 1485 & 2.44 & 64.98 & 154.56 & 5.03 \\
PGAf & 21.1 & 35.48 & 16.19 & 20.96 & 68.9 & 0.29 & 73.56 & 7.54 & 2.52 & 1541 & 2.62 & 59.62 & 155 & 3.44 \\
PGAc & 18.57 & 27.45 & 12.2 & 6.12 & 41.97 & 0.04 & 34.75 & 6.5 & 0.98 & 1373 & 2.99 & 70.16 & 80.12 & 9.17 \\
\hline
\end{tabular}



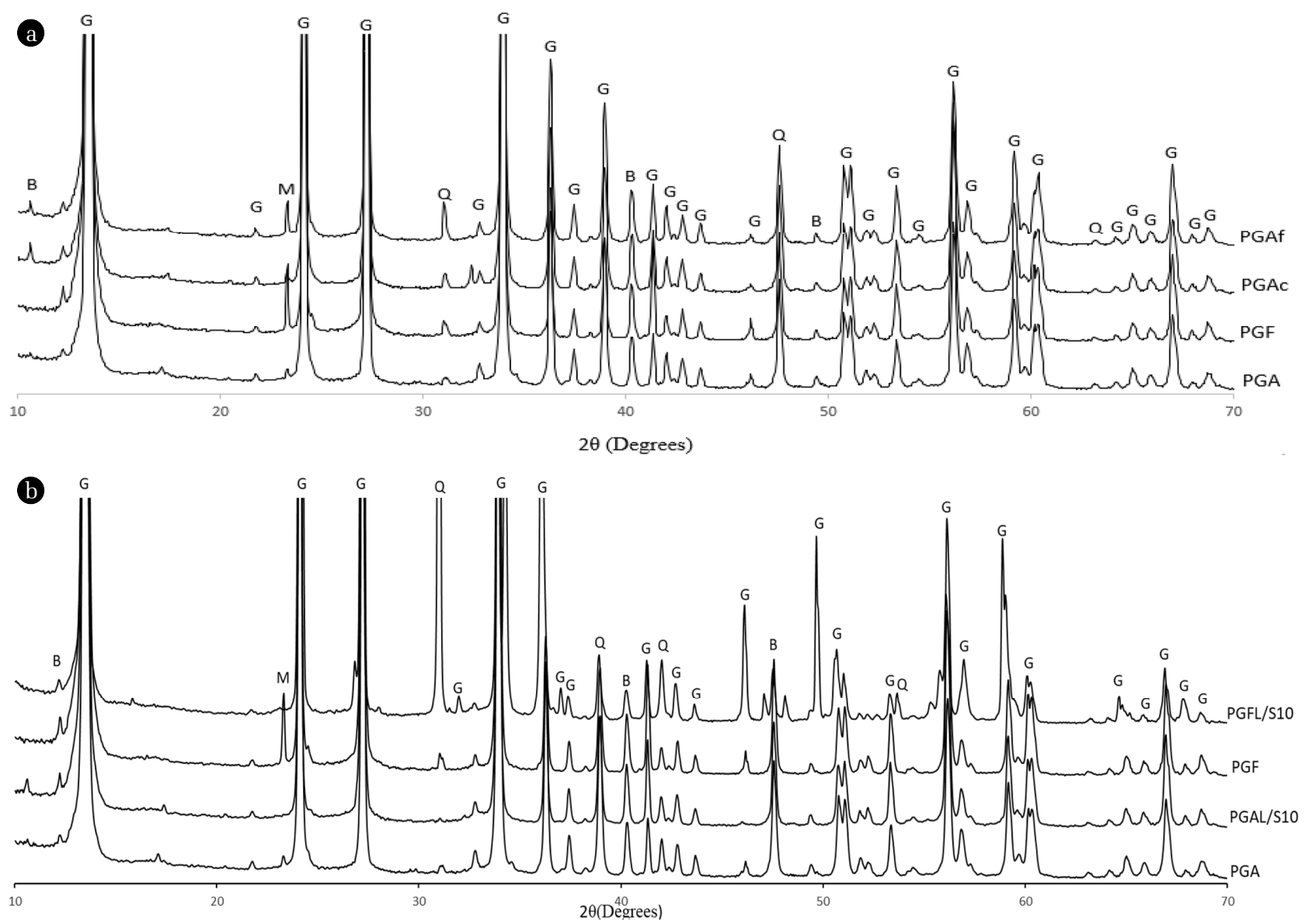

Fig. 3. XRD patterns of PG samples before (a) and after (b) leaching tests (G: Gypsum, B: Brushite, Q: Quartz, M: Malladrite).

as the reflection trends were almost unchangeable due to the presence of the same mineralogical phases. Such composition is consistent with the results of chemical analysis reported in Table 2. For Tunisian PGs, Ajam et al. [15] presented a unique mineralogical phase (i.e., gypsum), but Hammas-Nasri et al. [57, 58] and Hentati et al. [23] presented a heterogenous composition that is consistent with our results

\subsection{Leaching Behavior of Phophogypsum Samples}

Environmental risk assessment of a given waste mainly depended on the potential release of toxic chemical species, but not on the real contents. Indeed, the selection criteria of prospective industrial and/or environmental application of a by-product (e.g., PG waste) requires a preliminary evaluation of its environmental impact before and after its introduction in an integrative management scenario. In this section, several leaching tests was performed to quantify the leaching behavior of Tunisian PG.

\subsection{1. $\mathrm{pH}$ and $\mathrm{EC}$ variation during leaching test}

Measurements of equilibrium $\mathrm{pH}$ in leachates showed acidic $\mathrm{pH}$ conditions. Overall values of $\mathrm{pH}$ for PGF, PGA, PGAf and PGAc were, respectively, 2.6, 2.7, 2.3, and 2.8. This indicate the acidic nature due to the remaining traces of sulfuric acid added during the treatment process. Furthermore, eluates showed high electric conductivity (EC; 4-5 ms/cm) caused by the presence of many salts and ions. The high values measured for PG conductivity are related to salts dissolved during tests which can be associated to the lower $\mathrm{pH}$. $\mathrm{pH}$ value of PGF sample (2.3) was slightly lower than that of PGA (2.7) without affecting the leaching abilities of both samples because of the fact that $\mathrm{pH}$ of the leaching solution is a key parameter in the process [36].

\subsubsection{Leaching behavior}

The results of leaching tests showed that the most available elements are Calcium (Ca), Fluoride (F), Sodium (Na), Phosphorus (P) Sulfur (S) and Silicon (Si) (Table 4). These elements have the higher concentrations and higher leachability due to their availability. The most significant concentrations were related to calcium and sulfate; their presence in the studied samples depended mainly on gypsum solubility. The most mobile element was sodium of which more than $90 \%$ was washed away from PGA and PGF; the lowest leachable elements are Aluminum, Iron, Potassium, and Titanium.

Elements of environmental interest are Sulfur, Fluorine and Phosphorus of which the detected values largely exceeded the threshold limits desired by relevant regulations. Because of those 
Table 4. Chemical composition and properties of the leached elements concentrations of the studied phosphogypsum samples after EN 12457 $(\mathrm{mg} / \mathrm{kg})$

\begin{tabular}{|c|c|c|c|c|c|c|c|c|c|c|c|c|c|c|c|c|c|}
\hline & pH & EC & Ca & $\mathbf{F}$ & $\mathbf{P}$ & $\mathbf{S}$ & Si & As & Ba & Cd & $\mathrm{Cr}$ & $\mathrm{Cu}$ & $\mathbf{N i}$ & $\mathbf{P b}$ & Se & $\mathrm{Sr}$ & Zn \\
\hline PGF & 2.5 & 4.5 & 6,860 & 937.16 & 3,329 & $6,858.49$ & 2,709 & 0.80 & 0.81 & 1.29 & 3.12 & 0.3 & 0.45 & 0.13 & 0.91 & 79.16 & 4.47 \\
\hline PGA & 2.7 & 3.7 & 5,764 & 450.72 & 411 & 7,286 & 3,336 & 0.58 & 0.62 & 1.25 & 0.23 & 0.11 & 0.11 & 0.006 & 0.14 & 114.84 & 51.42 \\
\hline PGAf & 2.3 & 4.5 & 5,029 & 510.32 & 577 & 8,229 & 1,120 & 0.63 & 0.59 & 1.28 & 0.41 & 0.14 & 0.21 & 0.12 & 0.12 & 124.61 & 57.52 \\
\hline PGAc & 2.7 & 4.1 & 5,574 & 450.41 & 488 & 9,421 & 1,591 & 0.51 & 0.61 & 1.20 & 0.21 & 0.10 & 0.09 & 0.008 & 0.11 & 89.15 & 52.78 \\
\hline Inert & & & 5,000 & & & 6,000 & - & 0.5 & 20 & 0.04 & 0.5 & 2 & 0.4 & 0.5 & 0.1 & - & 4 \\
\hline Non hazardous & & & - & & & 20,000 & - & 2 & 100 & 1 & 10 & 50 & 10 & 10 & 0.5 & - & 50 \\
\hline Hazardous & & & - & 300 & 50 & 50,000 & - & 25 & 300 & 5 & 70 & 100 & 40 & 50 & 7 & - & 200 \\
\hline
\end{tabular}

Inert; non hazardous; hazardous are given by Decision 2003/33/CE

deleterious elements, the studied PGA and PGF phophogypsums can be classed as hazardous wastes. A special interest must be devoted to the management of those toxic elements before any possible valorization of PG to avoid its potential environmental impact.

Fluoride species is of environmental concern because of more than $1.5 \mathrm{mg} / \mathrm{L}$ in drinking water causes dental and skeletal fluorosis $[59,60]$. The high fluoride content is known to occur by the precipitation of CaF2. Extracts from Indian PG showed high fluoride contents reaching a maximum concentration of $149.5 \mathrm{mg} / \mathrm{L}$. The amount of fluoride leached from PG can be reduced with increasing $\mathrm{pH}$ of the leachate. Pérez-López et al. [10] have reported a good correlation between $\mathrm{pH}$ and $\mathrm{P}$ which is indicative of $\mathrm{H}_{3} \mathrm{PO}_{4}$ residual content.

As for trace elements, they were classified into three groups based on relevant normative thresholds. While eluate concentrations of As, $\mathrm{Cr}$ and $\mathrm{Ni}$ exceeded the European acceptance criteria for inert waste landfilling [61], leachate concentrations of $\mathrm{Ba}, \mathrm{Cu}$ and $\mathrm{Pb}$ are below the limit inert category [61]. Cd, Se and $\mathrm{Zn}$ showed high-enough values to be classed as hazardous materials.

$\mathrm{pH}$ is a critical parameter that significantly affect leaching behavior of trace elements [36]. In general, under acidic and oxide conditions, zinc is the most soluble and mobile cation which makes it the most phototoxic microelement after aluminum and manganese as zinc can easily migrate to the sandy and slightly acidic soil [53]. Under acidic conditions, the solubility of cadmium increases because of its predominant cationic species (i.e., $\mathrm{Cd}^{2+}$ ).

Leaching tests revealed high environmental risks with potential release of As, Zn Cd Se and Sr, calling for immediate measures to properly address the disposal of PG by-products.

\subsubsection{Effects of aging on leaching behavior}

A quick look to the chemical composition of fresh PGF and aged PGA PG samples shed light on the similar content of almost all major elements, with the exception of fluoride and phosphorus; both of them were released from the PGF with higher amounts. Fresh PGF sample have leached 22.9\% P and 8.03\% F, which are higher than the aged PGA sample release $3.29 \% \mathrm{P}$ and 7.04\%F).The released quantities are similar for $\mathrm{Ca}, \mathrm{S}$ and $\mathrm{Na}$.

The amounts of eluate concentrations of trace elements from fresh PG was slightly higher than from aged PG, except for Sr, Se and Zn that leached higher from aged PG. This trend agreed with the results of chemical analysis.

\subsubsection{Effects of grain size distribution on element mobility}

The effects of particle size distribution on leaching behavior of both PGA subsamples (i.e., PGAf and PGAc) shows similar solubili-
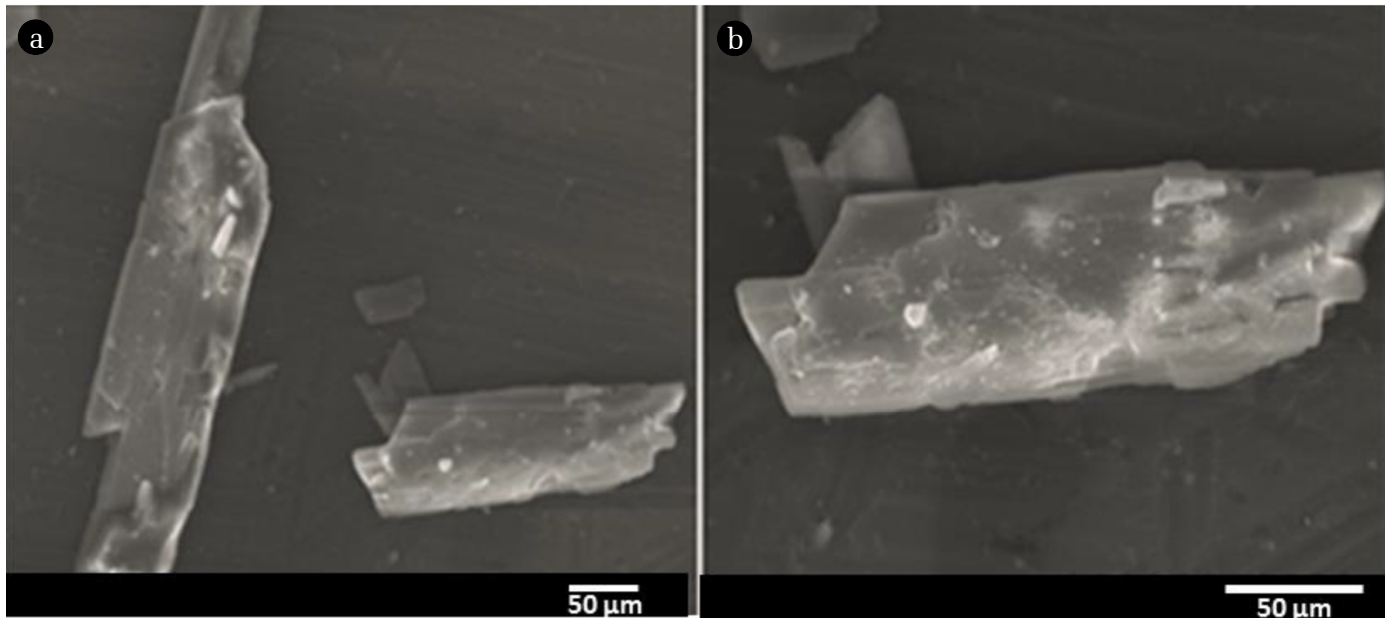

Fig. 4. SEM images (A: x250; B: X500) of leached PG sample. 
zation level for both subsamples studied. In addition, the major element contents of both fractions are very close to each other and to the raw PGA sample.

As for trace element contents (i.e., As, $\mathrm{Ba}, \mathrm{Cu}, \mathrm{Ni}, \mathrm{Pb}, \mathrm{Se}, \mathrm{V}$, Y), fine fraction showed relatively higher than coarse PGAc fraction, but $\mathrm{Cd}, \mathrm{Cr}, \mathrm{Sr}$ and $\mathrm{Zn}$ kept similar concentrations; their release did not correlate with the particle size distribution. This is an obvious conclusion that particle size distribution cannot affect the leaching ability of the studied PG samples. No clear difference between the release of metal species from both subsamples (i.e., PGAf and PGAc) was observed, further confirming the absence of significant effect on leaching process.

\subsubsection{Solid matrix alteration during leaching}

To identify the evolution of the solid matrix of the PG sample before and after leaching, mineralogical analysis and electron microscope observation was carried out on PG samples. Figure 3b shows the diffractograms of PG samples leached at liquid-solid ratio (L/S) of 10. The obtained results indicated an overlapping of X-ray diffractograms, showing similar mineralogical phases due to the mineralogical stability as already proved by the comparison between fresh and aged samples. The diffractograms made before and after leaching are also similar, further indicating similar composition.

SEM images, shown in Fig. 4, revealed an altered surface of the PG grain surface that kept its tabular shape. This may be plausibly explained by the effect of water erosion that contribute to the dissolution of the main adhering chemical elements associated with PG.

\section{Potential Application for an Integrated Management Approach}

This study provides an early insight on the leaching behavior of heavy metal from the PG embankment disposal of the Skhira treatment unit. Hitherto, PG management is limited to land disposal and controlled storage sites. We propose a management approach to valorize this by-product; save the cost of its storage and even make a financial profit as environmentally friendly process. The issue related to the reuse of Phosphogypsum is of great economic and environmental interest. Tunisian regulatory texts indicated that the previously adopted solution was limited to the installation of mono-dumps, managed by the producing industry. In Tunisia, land-based disposal storage has led to the constitution of large stocks in the cities of Sfax and Gabes, causing deleterious environmental effects [13]. Understanding the risks of heavy metals leaching from PG stacks during its life cycle is necessary, as highlighted in the present work. Further integrated management plan includes the potential application in construction materials such as plaster [16], concrete and construction demolition waste [62], polymer concrete [63]. PG can be used as a road base material, a developed approach to massively recycle PG for industrial application. It is to be mentioned that several attempts to sustainably valorize the high PG residues [15, 19, 33, 40, 64]. Moreover, Pérez-López et al. [65] provided geochemical data about stack-piles of PG from Huelva, Spain, with an aim to route for restoration plan. They recommended developing a treatment system for controlling outflow waters before the final discharge. Similarly, Papageorgiou et al. [11] proposed a photoremediation technique to mitigate the effect of trace element leaching. In this context, we propose to valorize PG for road base materials. Thus, the experimental design of the formulation mixtures will be optimized for better mechanical properties and strength performances.

The strength development (compressive, tensile strength as well as Young's modulus) at different curing times of the material will be studied and compared with conventional road base material. Our preliminary results about the potential use of recycled PG as a raw material for concrete were in perfect agreement with the findings of Manal [66], Rashad [67], Nizevičienè [64] and Chen [62]; it showed comparable properties as conventional road base materials. Hence, PG stacks can be engineered as a road base material with competitive properties. The possible use of PG as raw material supply for application in road and construction materials may adhere with the strategic management plan that meets the desired environmental requirements.

\section{Conclusions}

This study provides an early insight on the leaching behavior of heavy metal from the PG embankment disposal of the Skhira treatment unit (southern Tunisia).

It was concluded that high amounts of fines (65 to $75 \%$ by weight) significantly affected the leaching behavior of the studied PG samples. Geotechnical and mechanical properties of PG samples showed similar plasticity and great sensitivity to water. Mechanical properties of old PG are better than the fresh one. CBR was found to be much lower than that required by most specifications.

Chemical analysis showed heterogeneous distribution of heavy metals with an abundance of $\mathrm{Zn}$ and Sr compared to worldwide PG. There is no real visible trend to evaluate the behavior of the major /minor elements according to the age. This may promote the quantitative consideration of environmental impacts of PG but this information does not allow an efficient evaluation of chemical elements mobility.

Both PGs revealed high potential release of As, Zn, Cd Se and Sr further alarming the immediate adoption of suitable measures for safe disposal of PGs. Special care should be taken in the case of Se, Zn and Cd during the potential application of Tunisian PG. It is possible to propose a robust and coherent model that reproduces the leaching behavior, based on several input parameters.

\section{Acknowledgments}

We would like to thank Ms Helene Miche for technical assistance with the ICP-AES analyses. We applied the "sequence-determines-credit" approach (SDC) for the sequence of authors based on their declining contribution [68]. 


\section{References}

1. Koopman C, Witkamp G. Extraction of Lanthanides from the Phosphoric Acid Production Process to Gain a Purified Gypsum and a Valuable Lanthanide By-Product. Hydrometallurgy 2000;58:51-60.

2. Rentería-Villalobos M, Vioque I, Mantero J, Manjón G. Radiological, Chemical and Morphological Characterizations of Phosphate Rock and Phosphogypsum from Phosphoric Acid Factories in SW Spain. J. Hazard. Mater. 2010;181:193-203.

3. Fuleihan NF. Phosphogypsum Disposal-The Pros \&amp; Cons of Wet Versus Dry Stacking. Procedia Eng. 2012; 46:195-205.

4. Yun-jia W, Da-chao Z, Da-jun L, Yong-feng L, Xing-feng W. Environment Cumulative Effects of Coal Exploitation and Its Assessment. Procedia Earth Planet. Sci. 2009;1:1072-1080.

5. Rutherford PM, Dudas MJ, Arocena JM. Heterogeneous distribution of radionuclides, barium and strontium in phosphogypsum by-product. Sci. Total Environ. 1996;180:201-209.

6. Pérez-López R, Álvarez-Valero AM, Nieto JM. Changes in Mobility of Toxic Elements during the Production of Phosphoric Acid in the Fertilizer Industry of Huelva (SW Spain) and Environmental Impact of Phosphogypsum Wastes. J. Hazard. Mater. 2007;148:745-750.

7. Yang J, Liu W, Zhang L, Xiao B. Preparation of Load-Bearing Building Materials from Autoclaved Phosphogypsum. Constr. Build. Mater. 2009;23:687-693.

8. Al-Hwaiti M, Al-Khashman O. Health Risk Assessment of Heavy Metals Contamination in Tomato and Green Pepper Plants Grown in Soils Amended with Phosphogypsum Waste Materials. Environ. Geochem. Health 2015;37:287-304.

9. Pérez-López R, Castillo J, Sarmiento AM, Nieto JM. Assessment of Phosphogypsum Impact on the Salt-Marshes of the Tinto River (SW Spain): Role of Natural Attenuation Processes. Mar. Pollut. Bull. 2011;62:2787-2796.

10. Pérez-López R, Macías F, Cánovas CR, Sarmiento AM, Pérez-Moreno SM. Pollutant Flows from a Phosphogypsum Disposal Area to an Estuarine Environment: An Insight from Geochemical Signatures. Sci. Total Environ. 2016;553:42-51.

11. Papageorgiou F, Godelitsas A, Mertzimekis TJ, Xanthos S, Voulgaris N, Katsantonis G. Environment impact of Phosphogypsum stockpile in remediated schistos waste site (Piraeus, Greece) using a combination of y-Ray spectrometry with geographic information systems. Environ. Monit. Assess. 2016;188:133.

12. Kassir LN, Darwish T, Shaban A, Lartiges B, Ouaini N. Mobility of Selected Trace Elements in Mediterranean Red Soil Amended with Phosphogypsum: Experimental Study. Environ. Monit. Assess. 2012;184:4397-4412.

13. Maazoun H, Bouassida M. Phosphogypsum Management Challenges in Tunisia. In Contemporary Issues in Soil Mechanics. Springer, Cham, 2019;88-104.

14. Spoann V, Fujiwara T, Seng B, Lay C. Municipal Solid Waste Management: Constraints and Opportunities to Improve Capacity of Local Government Authorities of Phnom Penh Capital. Waste Manag. Res. 2018;36:985-992.

15. Ajam L, Ben Ouezdou M, Felfoul HS, Mensi R El. Characterization of the Tunisian Phosphogypsum and Its
Valorization in Clay Bricks. Constr. Build. Mater. 2009;23:32403247.

16. Moalla R, Gargouri M, Khmiri F, Kamoun L, Zairi M. Phosphogypsum Purification for Plaster Production: A Process Optimization Using Full Factorial Design. Environ. Eng. Res. 2017;23:36-45.

17. Szajerski P, Celinska J, Bem H, Gasiorowski A, Anyszka R, Dziugan P. Radium content and radon exhalation rate from sulfur polymer composites (SPC) based on mineral fillers. Constr. Build. Mater. 2019;198:390-398.

18. Chen Q, Zhang Q, Fourie A, Xin C. Utilization of Phosphogypsum and Phosphate Tailings for Cemented Paste Backfill. J. Environ. Manage. 2017;201:19-27.

19. Prasad MNV. Resource Potential of Natural and Synthetic Gypsum Waste. In Environ. Mater. Waste. Elsevier, 2016;307-337.

20. Papastefanou C, Stoulos S, Ioannidou A, Manolopoulou M. The Application of Phosphogypsum in Agriculture and the Radiological Impact. J. Environ. Radioact. 2006;89:188-198.

21. Abril JM, García-Tenorio R, Periáñez R, Enamorado SM, Andreu L, Delgado A. Occupational Dosimetric Assessment (Inhalation Pathway) from the Application of Phosphogypsum in Agriculture in South West Spain. J. Environ. Radioact. 2009;100: 29-34.

22. Crusciol CAC, Artigiani ACCA, Arf O, Carmeis Filho ACA, Soratto RP, Nascente AS, Alvarez RCF. Soil Fertility, Plant Nutrition, and Grain Yield of Upland Rice Affected by Surface Application of Lime, Silicate, and Phosphogypsum in a Tropical No-till System. CATENA 2016;137:87-99.

23. Hentati O, Abrantes N, Caetano AL, Bouguerra S, Gonçalves F, Römbke J, Pereira R. Phosphogypsum as a Soil Fertilizer: Ecotoxicity of Amended Soil and Elutriates to Bacteria, Invertebrates, Algae and Plants. J. Hazard. Mater. 2015;294: 80-89.

24. Li J, Liu Z, Zhao W, Masud MM, Xu R. Alkaline Slag Is More Effective than Phosphogypsum in the Amelioration of Subsoil Acidity in an Ultisol Profile. Soil Tillage Res. 2015;149:21-32.

25. Naifar I, Pereira F, Zmemla R, Bouaziz M, Elleuch B, Garcia D. Spatial Distribution and Contamination Assessment of Heavy Metals in Marine Sediments of the Southern Coast of Sfax, Gabes Gulf, Tunisia. Mar. Pollut. Bull. 2018;131:53-62.

26. Hammas-Nasri I, Horchani-Naifer K, Férid M, Barca D. Rare Earths Concentration from Phosphogypsum Waste by Two-Step Leaching Method. Int. J. Miner. Process. 2016;149:78-83.

27. Blott SJ, Pye K. GRADISTAT: A Grain Size Distribution and Statistics Package for the Analysis of Unconsolidated Sediments. Earth Surf. Process. Landforms 2001;26:1237-1248.

28. ASTM International. ASTM D1883: Standard Test Method for California Bearing Ratio (CBR) of Laboratory-Compacted. 2014.

29. Eka Putri E, V Kameswara Rao NS, Mannan MA. Evaluation of Modulus of Elasticity and Modulus of Subgrade Reaction of Soils Using CBR Test. J. Civ. Eng. Res. 2012;2:34-40.

30. Jiang Y, Wong LNY, Ren J. A Numerical Test Method of California Bearing Ratio on Graded Crushed Rocks Using Particle Flow Modeling. J. Traffic Transp. Eng. 2015;2:107-115.

31. Ghosh A. Compaction Characteristics and Bearing Ratio of Pond Ash Stabilized with Lime and Phosphogypsum. J. Mater. Civ. Eng. 2010;22:343-351.

32. Morel J-C, Pkla A, Walker P. Compressive Strength Testing 
of Compressed Earth Blocks. Constr. Build. Mater. 2007;21: 303-309.

33. Sfar Felfoul H, Clastres P, Ben Ouezdou M. Gestion Des Sous-Produits Industriels Et Developpement Durable : Cas Du Phosphogypse De Sfax (Tunisie). Sci. Technol. 2005;23:66-81.

34. Pansu M, Gautheyrou J. Handbook of Soil Analysis Mineralogical, Organic and Inorganic Methods. Berlin: Springer-Verlag; 2006.

35. Papaslioti E-M, Pérez-López R, Parviainen A, et al. Effects of Seawater Mixing on the Mobility of Trace Elements in Acid Phosphogypsum Leachates. Mar. Pollut. Bull. 2018;127:695-703.

36. Bisone S, Gautier M, Chatain V, Blanc D. Spatial Distribution and Leaching Behavior of Pollutants from Phosphogypsum Stocked in a Gypstack: Geochemical Characterization and Modeling. J. Environ. Manage. 2017;193:567-575.

37. Ben Salah I, Mbarek Jemaï M Ben, Sdiri A, Boughdiri M, Karoui N. Chemical and Technological Characterization and Beneficiation of Jezza Sand (North West of Tunisia): Potentialities of Use in Industrial Fields. Int. J. Miner. Process. 2016;148:128-136.

38. Rouis B. Contribution à l'utilisation de Sous-Produits Industriels : Application Au Cas Du Phosphogypse de Sfax (Tunisie), Université Joseph-Fourier - Grenoble I, 1991.

39. El Cadi A, Khaddor M, Lemee L, Amblès A. Journal of Environmental Solutions. J. Environ. Solut. 2012;1:34-40.

40. Sfar Felfoul H, Clastres P, Ben Ouezdou M, Carles-Gibergues A. Properties and Perspectives of Valorization of Phosphogypsum the Example of Tunisia. In Proceedings of International Symposium on Environmental Pollution Control and Waste Management, Vol. 3. 2002;510-520.

41. Schaeffner M. Premiers Résultats Relatifs Aux Conditions de Stockage et d'utilisation Du Phosphogypse Dans Les Remblais Routiers. LPC 1978; numéro spé.

42. Ben Salah I, Ben M’barek Jemaii M, Karoui-Yaakoub N, Sdiri A, Ben Ayed N, Boughdiri M. Properties of Debadib Evaporates (Northern Tunisia) for Potential Use in Industrial Fields. Open J. Geol. 2016;06:1525-1538.

43. Sdiri A, Bouaziz S, Sekrafi A. Properties of Mestaoua Evaporites (Southern Tunisia) for Plaster Industry. Carbonate. Evaporite. 2017;32:195-204.

44. Walawalkar M, Nichol CK, Azimi G. Process Investigation of the Acid Leaching of Rare Earth Elements from Phosphogypsum Using $\mathrm{HCl}, \mathrm{HNO}_{3}$, and $\mathrm{H}_{2} \mathrm{SO}_{4}$. Hydrometallurgy 2016;166:195-204.

45. Manal N, Samdi A, Elabassi K, Gomina M, Moussa R, Diouri A, Khachani N, Talbi MA. Recycling of Industrial Wastes, Phosphogypsum and Fly Ash, in Building Materials. Iind Int. Semin. Invaco - Innov. Valor. Civ. Eng. Constr. Mater. 2012.

46. Azouazi M, Ouahidi Y, Fakhi S, Andres Y, Abbe JC, Benmansour M. Natural Radioactivity in Phosphates, Phosphogypsum and Natural Waters in Morocco. J. Environ. Radioact. 2001.

47. Nasrellah H, Yassine I, Hatimi B, et al. New Synthesis of Hydroxyapatite from Local Phosphogypsum. J. Mater. Environ. Sci. 2017.

48. Gezer F, Turhan Ş, Uğur FA, Gören E, Kurt MZ, Ufuktepe Y. Natural Radionuclide Content of Disposed Phosphogypsum as TENORM Produced from Phosphorus Fertilizer Industry in Turkey. Ann. Nucl. Energy 2012;50:33-37.

49. Macías F, Pérez-López R, Cánovas CR, Carrero S, Cruz-Hernandez P. Environmental assessment and management of phosphogypsum according to european and United States of America Regulations. Procedia Earth Planet. Sci. 2017;17: 666-669.

50. Zmemla R, Naifer I, Benjdidia M, Elleuch B. Recycling of Tunisian Phosphogypsum as Road Material: Assessment of the Mechanical and Leaching Behavior. In Recent Advances in Environmental Science from the Euro-Mediterranean and Surrounding Regions. Springer Berlin Heidelberg, 2018; 1329 1332.

51. Bourgier V. Influence Des Ions Monohydrogénophosphates et Fluorophosphates Sur Les Propriétés Des Phosphogypses et La Réactivité Des Phosphoplâtres., Ecole Nationale Supérieure des Mines de Saint-Etienne, 2007.

52. Al-Hwaiti MS, Ranville JF, Ross PE. Bioavailability and Mobility of Trace Metals in Phosphogypsum from Aqaba and Eshidiya, Jordan. Chemie der Erde - Geochemistry 2010;70:283-291.

53. Al-Masri MS, Amin Y, Ibrahim S, Al-Bich F. Distribution of Some Trace Metals in Syrian Phosphogypsum. Appl. Geochem. 2004;19:747-753.

54. Shi Y, Gan L, Li X, He S, Sun C, Gao L. Dynamics of Metals in Backfill of a Phosphate Mine of Guiyang, China Using a Three-Step Sequential Extraction Technique. Chemosphere 2018;192:354-361.

55. Lenz M, Hullebusch ED Van, Hommes G, Corvini PFX, Lens PNL. Selenate Removal in Methanogenic and Sulfate-Reducing Upflow Anaerobic Sludge Bed Reactors. Water Res. 2008;42: 2184-2194.

56. Sdiri A, Higashi T, Bouaziz S, Benzina M. Synthesis and Characterization of Silica Gel from Siliceous Sands of Southern Tunisia. Arab. J. Chem. 2014;7:486-493.

57. Hammas I, Horchani-Naifer K, Férid M. Solubility Study and Valorization of Phosphogypsum Salt Solution. Int. J. Miner. Process. 2013;123:87-93.

58. Hammas-Nasri I, Horchani-Naifer K, Férid M, Barca D. Production of a Rare Earths Concentrate after Phosphogypsum Treatment with Dietary $\mathrm{NaCl}$ and Na2CO3 Solutions. Miner. Eng. 2019;132:169-174.

59. Vinati A, Mahanty B, Behera SK. Clay and Clay Minerals for Fluoride Removal from Water: A State-of-the-Art Review. Appl. Clay Sci. 2015;114:340-348.

60. Islam M, Patel RK. Evaluation of Removal Efficiency of Fluoride from Aqueous Solution Using Quick Lime. J. Hazard. Mater. 2007;143:303-310.

61. European Comission. The landfill Directive Council Directive 1999/31/EC. 2005;04523371.500:27-49.

62. Chen Q, Zhang Q, Qi C, Fourie A, Xiao C. Recycling Phosphogypsum and Construction Demolition Waste for Cemented Paste Backfill and Its Environmental Impact. J. Clean. Prod. 2018;186:418-429.

63. Szajerski P, Bogobowicz A, Bem H, Gasiorowski A. Quantitative Evaluation and Leaching Behavior of Cobalt Immobilized in Sulfur Polymer Concrete Composites Based on Lignite Fly Ash, Slag and Phosphogypsum. J. Clean. Prod. 2019;222:90-102.

64. Nizevičienė D, Vaičiukynienė D, Michalik B, Bonczyk M, Vaitkevičius V, Jusas V. The Treatment of Phosphogypsum with Zeolite to Use It in Binding Material. Constr. Build. Mater. 2018. 
65. Pérez-López R, Nieto JM, de la Rosa JD, Bolívar JP. Environmental Tracers for Elucidating the Weathering Process in a Phosphogypsum Disposal Site: Implications for Restoration. J. Hydrol. 2015;529:1313-1323.

66. Manal N, Samdi A, Elabassi K, Gomina M, Moussa R. Recycling of industrial wastes, phosphogypsum and fly ash, in building materials - Recyclage de dechets industriels, phosphogypse et cendres volantes, dans des materiaux de construction. In: MATEC Web of Conferences; 3 September 2012; Rabat.

67. Rashad AM. Phosphogypsum as a Construction Material. J. Clean. Prod. 2017;166:732-743.

68. Tscharntke T, Hochberg ME, Rand TA, Resh VH, Krauss J. Author Sequence and Credit for Contributions in Multiauthored Publications. PLoS Biol. 2007;5:e18. 